\title{
Outdoor School: Creating A Passion for the Environment
}

\author{
Diana Flannery ${ }^{1}$, Mary Portis ${ }^{1}$, Alicia Eller $^{2}$, \& Mark Stemen ${ }^{1}$ \\ California State University, Chico ${ }^{1}$ \\ Naturalists At Large ${ }^{2}$
}

\begin{abstract}
Environmental education aids in creating deeper understanding, investigation, and decision-making skills among students. The goal of environmental education is to lead students to become effective environmental stewards. We created an ongoing service learning partnership that combines mentoring, environmental education, and community resources with elementary and college students in an Outdoor School program. This paper outlines the process and content of Outdoor School.

(C) 2003 Californian Journal of Health Promotion. All rights reserved. Keywords: Environmental Education, Service Learning, Environmental Health, Outdoor Education
\end{abstract}

\section{Introduction}

We teach environmental awareness to children and college students. We want both groups to become environmentalists in their own homes, communities and personal actions but beyond participation in a structured recycling program or community clean up our students often don't express environmental values or initiate environmental actions. No matter how many facts, videos and stories we share about the state of our world the majority of our students continue to be apathetic and even overwhelmed. Why, when there are so many ways to be environmental stewards, are they so apathetic? How do we provide our youth with other opportunities besides "digital woods to play in or paved playgrounds to run around on (Ayers, 1999)?" As children turn to technology and the entertainment industry, they are becoming less in contact with the physical world thus losing their great capabilities to respond heroically to challenges or threats to the environment. There needs to be more opportunities for students to engage in an awareness and appreciation of our natural world. We still do the essential recycling and community clean ups, but to help support an appreciation for the physical world and to create a sense of place in their own community, we have introduced an environmental education program that partners local elementary children and college students. Together, this program aids our children and young adults to discover why the environment is important.

\section{What is Environmental Education?}

Environmental education has been defined as a process that aims to develop an environmentally literate citizenry who may be competitive in the global economy (National Project for Excellence in Environmental Education, 1993), and who may develop the skills, knowledge, inclinations to make well-informed choices, and exercise their rights and responsibilities as members of the community. Environmental education has the potential to increase the overall amount of time teachers spend on the environment each school year and aids in creating deeper understanding, investigation, and decisionmaking skills among students. The goal is to lead students to become effective environmental stewards (The National American Association for Environmental Education, 2001).

The California Department of Education challenges educators to be leaders in environmental education and outlines their goals in, "Education and the Environment/ Strategic Initiatives for Enhancing Education in California" (2002). The report argues that environmental-based education helps students to feel more confident, to feel part of their community, and to think. Moreover, students 
who participate in environmental education are better able to learn, to be citizens at school, and to transfer their learning to new situations. The ultimate goal of the plan is to give students a better chance to become the best citizens possible.

There are many environmental education curricula available to help you meet program goals in community settings. The North American Association for Environmental Education (2001) provides guidelines to specify what to look for in environmental education (EE) materials. The guiding principles for EE materials should:

- Be fair and accurate in describing environmental problems, issues and conditions, and in reflecting the diversity of perspectives on them;

- Provide knowledge presented in depth as appropriate for different development levels;

- Build on lifelong skills that enable learners to address environmental issues and to prevent problems

- Focus on an orientation to action that promotes civic responsibility and problem solving and action
- Include instructional techniques that create an effective learning environment;

- Be well designed and easy to use.

With these goals and principles in mind, we created an ongoing service learning partnership that combines mentoring, environmental education, and community resources with elementary and college students in an Outdoor School program.

\section{What is Outdoor School?}

Outdoor School takes place at an outdoor site away from the school. For us, Outdoor School takes place on a 93 -acre ecological reserve in a canyon in the foothills of the Sierras, called the Butte Creek Ecological Reserve Outdoor Classroom (Figure 1). It is less than ten miles from the university and the elementary school. Outdoor School can take place anywhere there is a natural environment. Outdoor School is a full day of environmental activities targeted toward fourth through sixth grade students and led by university students. The activities included in Outdoor School teach environmental health as well as outdoor safety and fitness concepts by incorporating movement, discovery, art, poetry, restoration, experimentation, drama and music.

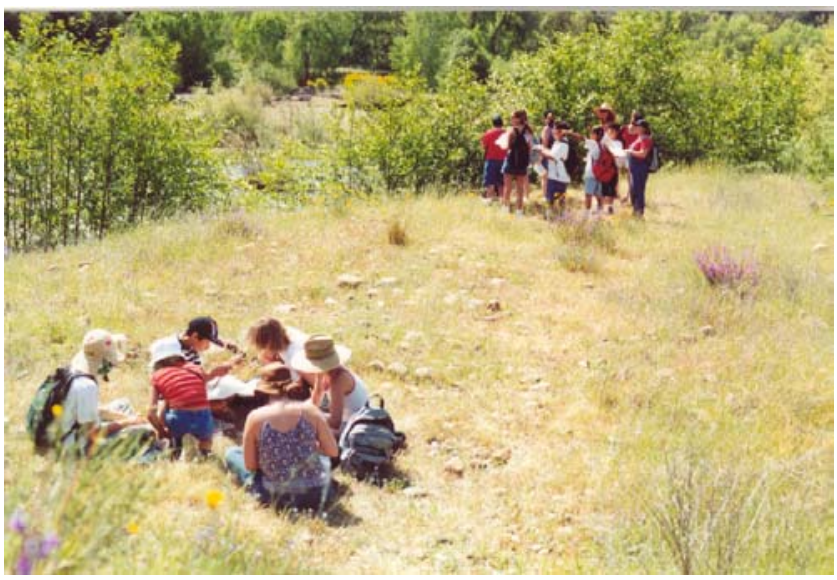

Figure 1

Outdoor School Groups Working Together

The Outdoor School we have described was developed through experimentation with many activities and approaches over three years.
While we are always looking for different experiences, we feel comfortable with the type of offerings and timing of the day. University 
and elementary school students are both tired at the end of the day and both express enthusiasm about the variety of their experiences. Regardless of the offerings that meet the needs of your audience, we find that adherence to Joseph Cornell's trademarked, "Flow Learning" (1979) creates a powerful teaching and learning process that brings children and young adults naturally and deeply into inspiring experiences of nature. These are the stages of Flow Learning:

- Stage 1: "Awaken Enthusiasm," uses activities that develop alertness and playfulness, create involvement, and generate good group dynamics.

- Stage 2: "Focus Attention," is a transitional stage. These activities deepen awareness, develop observational skills, calm the mind, and develop receptivity for more sensitive nature experiences.

- Stage 3: "Direct Experience," is when children encounter nature directly, with activities that foster wonder, empathy, and love for nature.

- Stage 4: "Share Inspiration," clarifies and strengthens the personal experiences with nature.

\section{The Objectives of Outdoor School}

For the children the objectives of Outdoor School are:

- Describe ways to protect the environment.

- Demonstrate outdoor safety skills.
- Explore healthy, active, environmentally sound recreational activities in the local area.

- Demonstrate ways to enjoy natural places while protecting the plants and animals that live there.

- Describe what you see, hear, feel, taste and appreciate about our natural world.

For the university students taking the environmental health course, the objectives of Outdoor School include all of those above as well as:

- Integrate environmental health facts and safety procedures into an entertaining, ageappropriate outdoor safety skit.

- Facilitate discovery and learning for a group of fourth through sixth graders.

- Practice a variety of teaching strategies with upper elementary grade students.

- Analyze personal strengths and weaknesses in teaching and leading others in environmental health activities.

- Evaluate and revise environmental health activities based on experience in the field.

\section{Materials for Outdoor School}

Each university student and elementary student receives a packet of activities in a hard folder, a pencil made of recycled motor oil and filters, a water bottle, a hat, and a magnifying glass. A local farmer provides a variety of watermelon for a mid-afternoon snack (Figure 2).

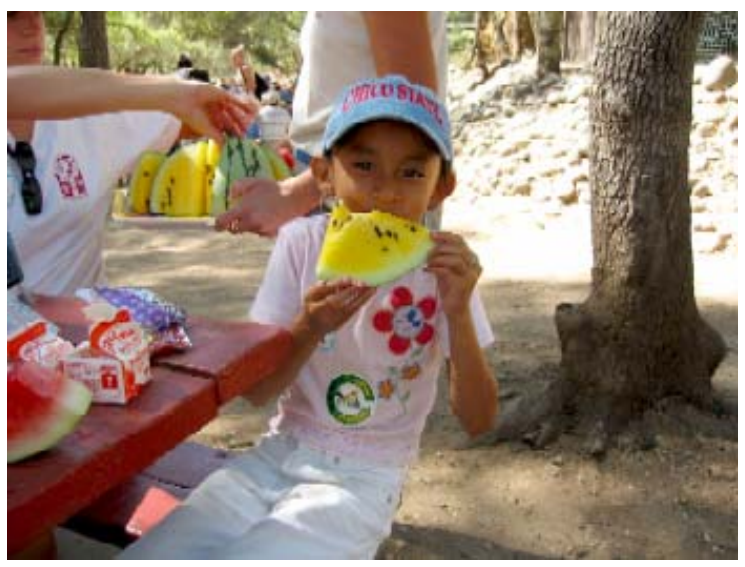

Figure 2

Girl Eating Watermelon 


\section{The Contents of Outdoor School}

\section{Stage 1: Awaken Enthusiasm}

Outdoor School begins when the university students greet the school bus filled with elementary students and find their group members by identifying individuals wearing the same nature sticker on their name tag. Group members introduce themselves and wander into a large meeting with hay bails placed in a semicircle for seating. A welcome to Outdoor School is issued along with the rules: 1) Show respect for each other and the environment; 2) Follow directions; and 3) Have fun. Then the children and students participate in a variety of "getting-to-know-you" activities, followed by a group meditation that encourages everyone to quietly observe and listen.

\section{Stage 2: Focus Attention}

For the next thirty to forty-five minutes, the children are presented with a variety of environmental and safety skits on the following topics: biomagnification (Figure 3), water safety, fire safety, rattlesnakes, poison oak (Figure 4), ticks, getting lost, sun safety, lifecycle of the salmon (Video Clips $1 \& 2$ ), and first aid. All of the skits require audience participation.

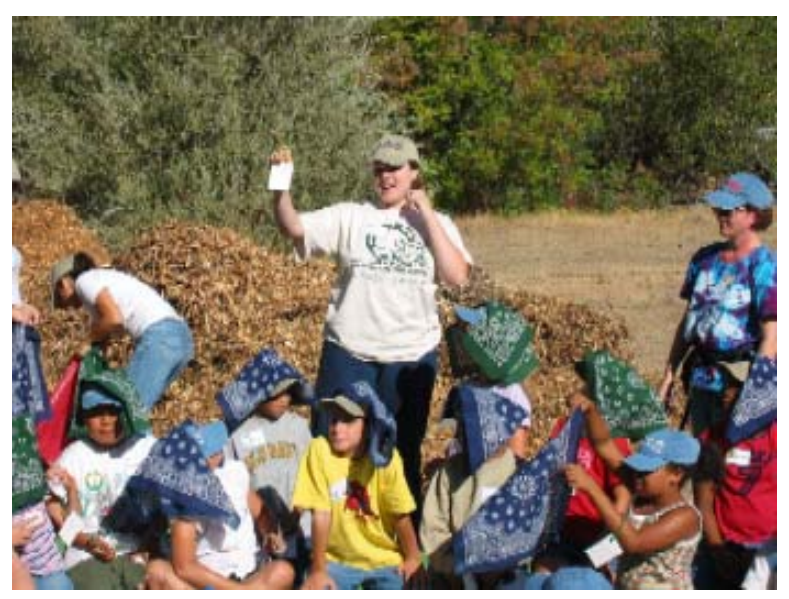

Figure 3

Students Leading Biomagnification Activity

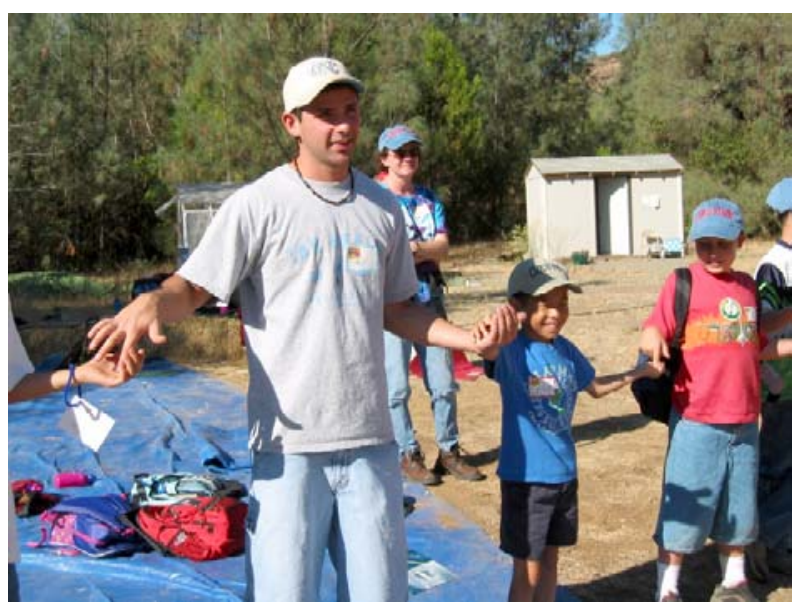

Figure 4

Poison Oak Game 


\section{Stage 3: Direct Experience}

Following the skits, each group of two university students and five elementary students sets off to explore the 93 undeveloped, natural acres each armed with a field packet full of exploration activities. One of the first activities is a Sock Walk where each individual pulls an old sock over one shoe and hikes around picking up all kinds of seeds. After they have accumulated a lot of debris, the socks are analyzed under the magnifying glasses and charted on one of the pages of their activity book (Figure 5). Other pages have woodland scavenger hunts, bird watching bingo, animal tracking, making trail markers, identifying spiders by their webs, and blind walks. References with good activities for children are included in our reference section.

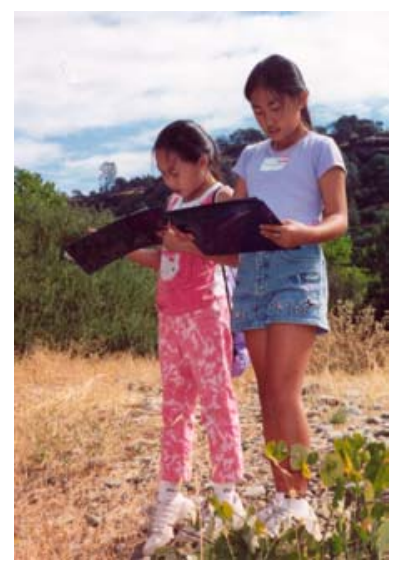

Figure 5

Girls Completing an Activity in the Packets

During this exploration time (seventy-five to ninety minutes) groups are encouraged to see and do as many different things as possible. As they explore, the groups discover stations that have been set up for them to observe salmon or other fish, watch for frogs, plant native trees and grasses (Figure 6), and build trails. After exploration it is time for lunch. Groups stay together during this time and once everyone has finished eating there is a period of free play (Figure 7, Video Clip 3 Near The Creek).

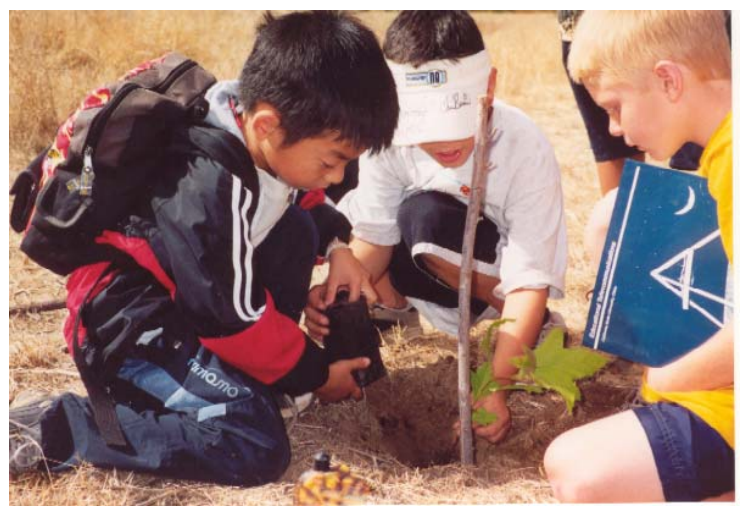

Figure 6

Boys Planting Native Trees 


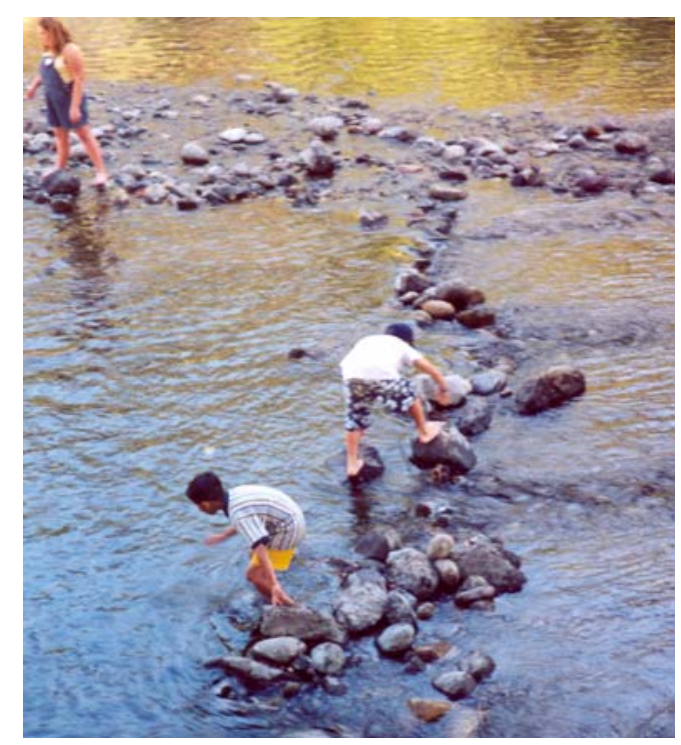

Figure 7

Free Play in Creek After Lunch

\section{Stage 4: Share Inspiration}

The afternoon (ninety minutes) is devoted to reflecting and expressing what was discovered, learned and thought. This is facilitated through the use of crafts, music, poetry and art.
Our crafts include creating pine cone bird feeder (Figure 8) out of a pine cone, peanut butter, bird seed and string; painting what one was most impressed by with watercolors (Figure 9); leaf rubbings with environmental messages added; and "medallions" made out of wood discs cut from branches.

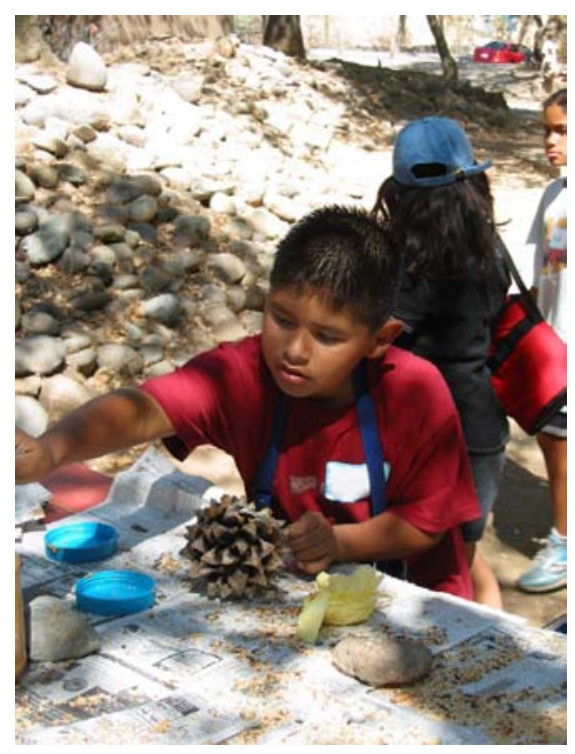

Figure 8

Making a Bird Feeder 


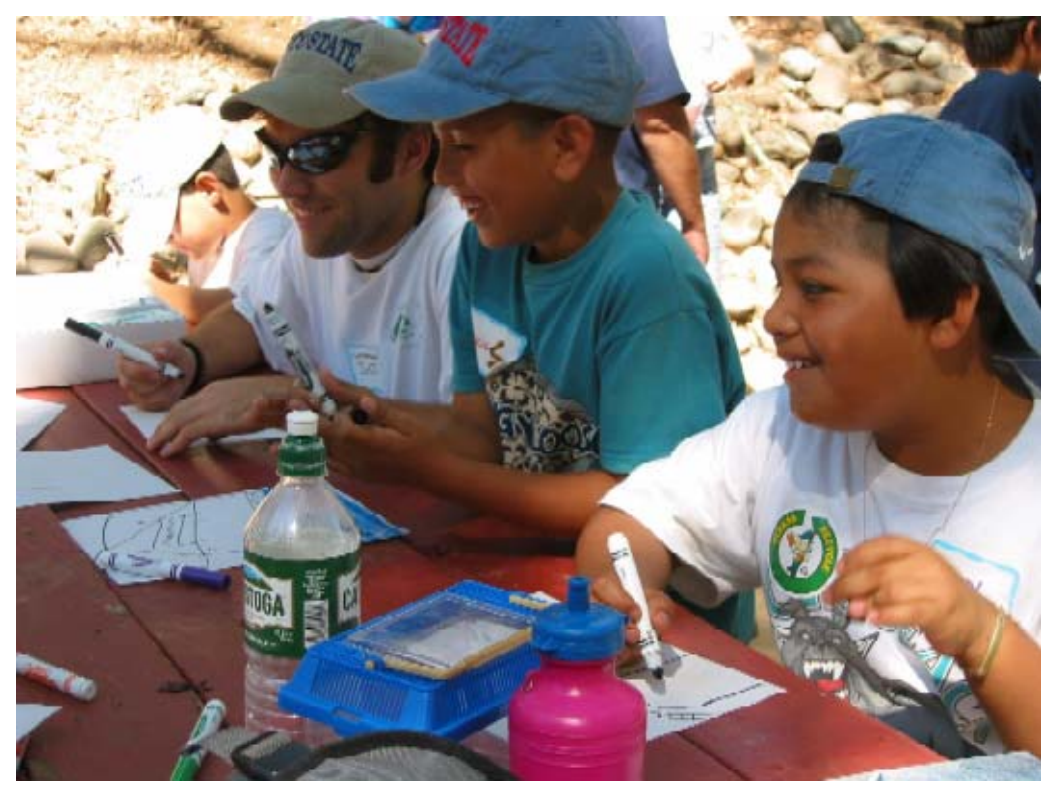

Figure 9

Drawing, Painting and Sharing

Poetry is written individually and shared with the group. Students have a choice of Haiku, Cinquain, or Free Verse. Directions and examples are given for all three types of verse in the packet of materials. As a final part of the day, the entire group gathers together to sing

\begin{tabular}{|c||}
\hline Pledge to the Earth \\
I pledge allegiance \\
To the earth \\
And all of the \\
Life \\
which it supports. \\
One planet, \\
In our care, irreplaceable, \\
With sustenance and \\
Respect for all! \\
\hline
\end{tabular}

Figure 10

Pledge to the Earth songs, share their insights and say the pledge to the earth (Figures $10 \& 11$ ). For video clips of the singing event, see Video Clip 4 CSU, Chico Students Singing in a Group with Children, and Video Clip 5 Children Singing.

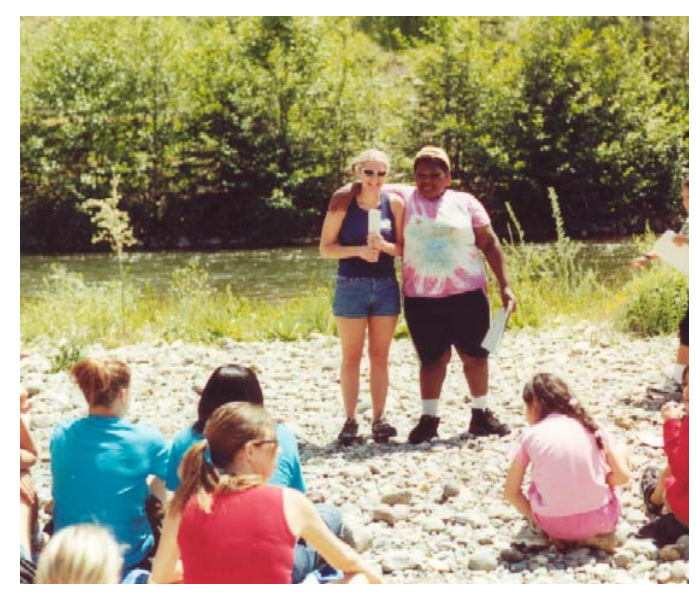

Figure 11

University Student and Elementary Student Share Their Findings 


\section{Follow Up to Outdoor School}

For the regular classroom teachers of the elementary students, Outdoor School is the beginning of a larger unit on the environment taught both in both health and science classes. Thank you notes and pictures allow for reflection after they return to their classrooms. Photographs we send in the days that follow provide writing prompts in their language arts classes.

For the university students Outdoor School is a culminating activity where they, future health educators, were able to practice their planning, tailoring, and teaching skills in an nontraditional setting with a small group of interested learners. To make connections between the class and their experience, students are asked to respond to a series of reflective questions.

- What were your strengths at Outdoor School?

- What challenges did you face at Outdoor School? How did you respond to these challenges?

- What did you learn about children and their needs in environmental education as a result of Outdoor School?

- How did your participation in Outdoor School help make you a better advocate and citizen?

- How has Outdoor School helped you learn more about environmental health in your local community?

- How have your class readings and discussions enhanced your environmental awareness or activism?

- What have you learned about yourself as a result of Outdoor School?
- Identify ways to make the Outdoor School experience more effective for other university students and elementary students.

\section{Student Reflections}

After Outdoor School, children vibrate with enthusiasm about the environment. They revel in their sightings of animals, reptiles and fish. They brag about the distance they hiked. They laugh about the fun things they did with their university leaders. They write about the beauty of the outdoors and why we need to protect it. They think of questions about the environment and nature. They ask when they can go to Outdoor School again.

After Outdoor School, university students express surprise about how meaningful Outdoor School was to the children in their groups. They are shocked that experiences they took for granted such as hiking, camping, going to a nature center, seeing wildlife, exploring a natural area were entirely new experiences for the children. They are pleased and surprised that the children liked them so much so quickly. They looked at their own abilities to teach and influence others more seriously and saw that health education brought satisfactions they hadn't expected.

\section{Summary}

A day outside (Figure 12) in a summer camp atmosphere may be just the antidote needed to fight student apathy about protecting our environment. Take the time to develop a passion for nature in your students and they may respond with a passion for the environment. 


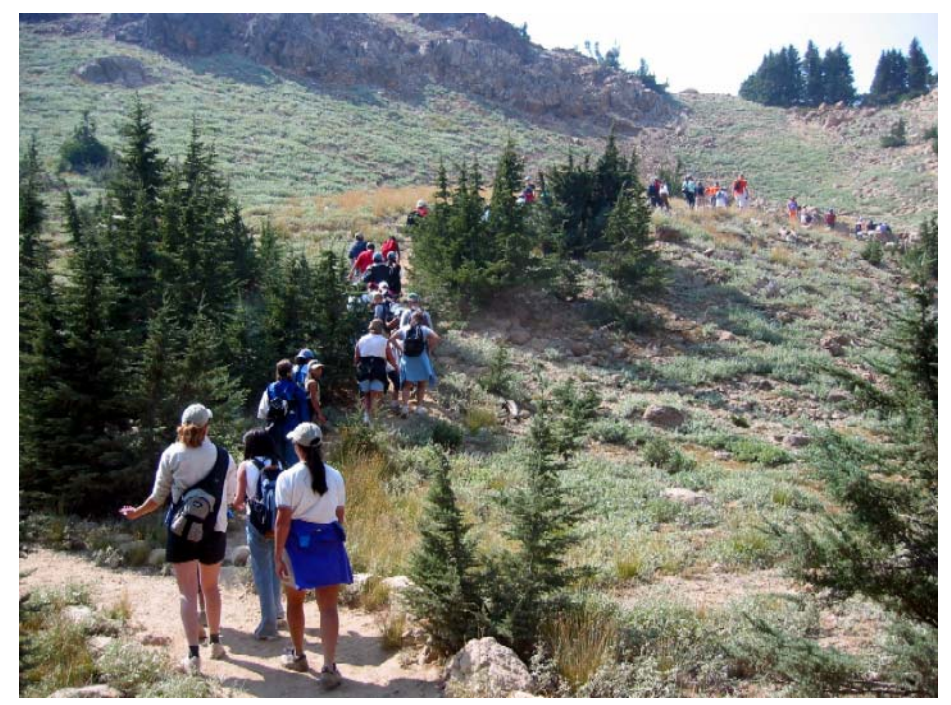

Figure 12

Hiking Home

\section{References}

Ayers, E. (1999). Why are we not astonished? World Watch, 12(3), 25-29.

California Department of Education. (2002). Education and the environment: Strategic initiatives for enhancing education in California. Retrieved February 7, 2003, from http://www.cde.ca.gov/cilbranch/oee/caplan.pdf

Community-Campus Partnerships for Health. (2003). Home page. Retrieved February 7, 2003, from http://futurehealth.ucsf.edu/ccph.html

Cornell, J. (1979). Sharing nature with children. Nevada City, CA: Dawn Publications.

Dendy, L. (1995). Tracks, scats and signs. Minnetonka, MN: North Word Press.

Lachecki, M. \& Kasperson, J. (1995). More teaching kids to love the earth. Duluth, MN: PfeiferHamilton.

Olmstead, A. (2000). My nature journal. Oregon, IL: Quality Books.

The North American Association for Environmental Education. (2001). Using environment-based education to advance learning skills and character development: A report, annotated bibliography, and research guide. Washington. DC. The National Environmental Education and Training Foundation. Retrieved February 7, 2003, from http://www.neetf.org/pubs/EnviroEdReport.pdf

\section{Acknowledgements}

This project was funded by a contract with Butte County Office of Education and by a Strategic Performance Grant Fall 2002 to D. Flannery from the CSU, Chico College of Behavioral and Social Sciences.

Special thanks to:

Department of Health and Community Services, California State University, Chico Butte Creek Ecological Reserve

Chapman Elementary School 
$\underline{\text { Author Information }}$

Diana Flannery, $\mathrm{PhD}$

Department of Health and Community Services

California State University, Chico

E-Mail: dflannery@,csuchico.edu

Mary Portis, DrPH

Department of Health and Community Services

California State University, Chico

E-Mail: mportis@csuchico.edu

Alicia Eller, Naturalist

Naturalists At Large

Ventura, CA

Mark Stemen, $\mathrm{PhD}$

Assistant Professor \&

Coordinator of the Environmental Studies Program

Department of Geography and Planning

California State University, Chico

E-Mail: mstemen@,csuchico.edu 